\title{
PEREMPUAN DAN BENCANA: MEMBERDAYAKAN POTENSI SOSIAL DAN EKONOMI PEREMPUAN KORBAN BANJIR LAHAR DINGIN MERAPI
}

\author{
Yulianingsih Riswan dan Diah Arifika \\ Email: yuliariswan@gmail.com
}

\begin{abstract}
This paper investigates the impacts of disaster on women in nearby areas. It specifically addresses women's experiences following the Merapi eruptions while staying in a Huntara (Hunian Sementara / Temporary Shelter) in Gempol Jumoyo village, Magelang. The purpose of this paper is to explore women's role in the disaster and to locate domains where women are most affected by it. This paper draws on qualitative research conducted with a number of women in the Huntara. Data was collected through observation, in-depth interviews, and textual documents. The result of this research paper is that disasters affect not only the lives of victims, but also people's social and cultural dimensions. Through an investigation of three domains of women (group, work, and family), this study shows how disasters severely affect human life, as well as exposing the resilience of women in disaster areas.
\end{abstract}

Keywords: Women, Disaster, Resilience

ABSTRAK

Paper ini menginvestigasi dampak bencana untuk wanita di daerah terdekat. Ini khusus membahas pengalaman perempuan pasca-letusan Merapi di huntara (Hunian Diperbaiki / Tempat Tinggal Sementara) dari Gempol Jumoyo desa di Magelang. Tujuan dari makalah ini adalah untuk mengeksplorasi peran perempuan dalam bencana dan untuk mencari domain di mana sebagian besar perempuan yang terpengaruh olehnya. Hal ini mengacu pada penelitian kualitatif dilakukan untuk sejumlah perempuan di huntara. Data dikumpulkan dari pengamatan, wawancara mendalam, serta dokumen-dokumen tekstual. Hasil dari penelitian ini adalah bahwa tidak hanya bencana mempengaruhi kehidupan ekonomi para korban, tetapi juga dimensi sosial dan budaya rakyat. Melalui penyelidikan dari tiga domain perempuan, kelompok, pekerjaan, dan keluarga, studi ini menunjukkan bagaimana bencana sangat mempengaruhi kehidupan manusia, serta mengekspos ketahanan perempuan di daerah bencana.

Kata kunci: Perempuan, Bencana, Ketahanan 


\section{PENGANTAR}

Letusan Gunung Merapi yang terjadi pada tanggal 26 Oktober 2010, disusul dengan letusan besar pada tanggal 28-29 Oktober 2010 dan tanggal 5 Nopember 2010, telah menyemburkan material vulkanik disertai awan panas setinggi 1,5 km. Selain awan panas yang berbahaya, timbul bahaya sekunder, yaitu berupa lahar dingin yang membawa material letusan Merapi dan berdampak pada rusak dan tertimbunnya beberapa wilayah, khususnya di sekitar aliran sungai Gunung Merapi. Oleh karena itu, penduduk yang terkena dampak aliran lahar dingin perlu diberikan bantuan tanggap darurat, seperti hunian sementara, normalisasi prasarana, sarana umum, dan juga pemanfaatan lahan-lahan pertanian.

Sesuai Undang-Undang Nomor 24 Tahun 2007 tentang Penanggulangan Bencana dan Pengaturan Pelaksanaannya, agar diberlakukan tahap transisi darurat ke pemulihan sebagai dukungan bagi masyarakat untuk memulai kehidupannya terutama usaha dan pekerjaan, sambil menunggu tahap rehabilitasi dan rekonstruksi dipersiapkan dengan baik. Penilaian kerusakan dan kerugian (Damage and Loss Assesment/DaLA) merupakan upaya untuk mendapatkan gambaran komprehensif dampak langsung dan tidak langsung dari bencana yang meliputi kerusakan fisik dan kerugian ekonomi (PTO Pelaksanaan Kegiatan Padat Karya Pemulihan Pasca Bencana Merapi, PNPM Mandiri Perkotaan Kabupaten Magelang, 2010).

Berdasarkan jenis kerusakan yang terjadi, pemulihan ekonomi masyarakat korban bencana erupsi dilakukan di subsektor pertanian, perkebunan, kehutanan, peternakan, perdagangan, industri kecil, koperasi, dan perikanan. Di dalam pemulihan ekonomi jangka pendek adalah melalui kegiatan padat karya oleh lembaga swasta bekerjasama dengan pemerintah melalui skema Cash for Work (CfW), kegiatan ini sekaligus dapat menyediakan lapangan kerja bagi masyarakat secara tepat guna dan memberikan stimulus bagi perekonomian lokal untuk menyediakan peluang-peluang ekonomi produktif.

Di lain pihak, erupsi Merapi yang terjadi pada akhir tahun 2010 tidak hanya menimbulkan kerugian bagi masyarakat, melainkan ada keberkahan yang dapat langsung dinikmati dan dimanfaatkan, yaitu kelimpahan material Merapi berupa pasir dan bebatuan. Masyarakat tidak serta-merta kehilangan semua aset dan peluang kerja, namun terjadi perubahan pengembangan sektor ekonomi, yaitu dari pertanian, peternakan, dan perikanan menjadi peluang usaha material. Perubahan pola pengembangan ekonomi ini tentu saja berdampakpadaalurkehidupansosiallainnya. Siklus waktu bekerja, jumlah penghasilan, dan pengelolaan penghasilan tentu juga mengalami perubahan. Sumberdaya manusia juga ikut diperhitungkan. Laki-laki maupun perempuan semua terlibat dalam program padat karya atau menjadi penambang pasir untuk memenuhi kebutuhan finansial saat itu.

Perempuan dengan segala faktor alamiahnya yang lebih dekat dengan nature atau alam diyakini memiliki kesamaan sifat, yaitu memberi. Sawah dan lahan pertanian pun menjadi "ruang" yang cocok bagi perempuan untuk bekerja karena pertanian tidak hanya bertumpu pada kekuatan fisik semata. Sementara itu, sungai, jalan, dan pertambangan pasir adalah wilayah yang berisiko tinggi bagi fisik perempuan. Pasca erupsi Merapi, perempuan semakin banyak yang masuk ke wilayah ini karena tertutupnya lahan pertanian dengan abu Merapi dan perubahan pola hidup bisa dilihat dari kondisi alih profesi ini. oleh karena itu, penelitian ini dilakukan untuk mengetahui perubahan-perubahan tersebut, mencari peluang pengembangkan model manajemen potensi sosial ekonomi khususnya bagi perempuan yang berdampak pada kesejahteraan keluarga dan bagi masyarakat secara umum.

Penelitian ini mengambil tempat di Dusun Gempol, Desa Jumoyo, Kecamatan Salam, Kabupaten Magelang Jawa Tengah. 
Daerah ini menjadi pilihan karena terletak di bantaran Kali Putih, yaitu sungai yang menjadi jalan bagi kumpulan material yang berasal dari kawah Gunung Merapi. Perubahan letak dan kondisi geografis yang semakin menyempit dan dangkalnya aliran sungai menyebabkan air yang membawa materi berupa pasir dan bebatuan meluap hingga menimbun rumah-rumah warga. Akibatnya, warga harus mengungsi untuk menyelamatkan diri dari material lahar dingin.

Dampak lain adalah alih profesi warga dari bertani menjadi penambang pasir karena lahan sawah yang tertimbun material belum dapat ditanami kembali. Padahal, sebagian besar kehidupan masyarakat mengandalkan penghasilan dari sawah atau ternak. Terjadinya bencana telah merusak rumah, aset, dan simpanan masyarakat setempat. Menurut Amartya Sen (2005), ketahanan masyarakat korban bencana yang tinggal di desa menjadi sangat singkat dan pendek dibandingkan masyarakat yang tinggal di kota, karena warga kota sebagian besar menyimpan aset dan kekayaannya tidak hanya di satu tempat, yang antara lain bisa berupa uang di bank atau aset di beberapa perusahaan, sedangkan masyarakat desa menyimpan harta benda (rumah, lahan, dan ternak) dalam satu lokasi yang berdekatan, akibatnya ketika bencana datang semua harta dan simpanan ikut terbawa.

Tulisan ini bertujuan mengkaji respons masyarakat di wilayah kawasan banjir lahar dingin Merapi, sekaligus melihat dampak bencana pada sektor sosial dan ekonomi masyarakat. Perempuan menjadi subjek utama selain karena jumlahnya yang banyak, juga karena posisinya yang strategis. Perempuan dalam bencana dapat menjadi jembatan bagi korban bencana lain yaitu anak-anak dan orang lanjut usia. Oleh karena itu, perempuan menjadi kunci yang tepat untuk masuk dalam memahami risiko bencana sekaligus ketahanan masyarakat dalam menghadapi bencana.

Penelitian tentang bencana telah dilakukan oleh berbagai pihak dengan mengambil beberapa fokus, baik dari sisi geologis, lingkungan, maupun dari sisi etika agama. Berbagai penelitian yang dimotori Program Studi Agama dan Lintas Budaya UGM, misalnya, secara khusus melihat fenomena bencana dari kaca mata agama, di antaranya Pengaruh Agama terhadap Kecemasan Anak Pasca Gempa 27Mei 2006: Studi Kasus GKJ Gantiwarno oleh Guno Tri Tjahyoko, Santri Tanggap Bencana (Santana): Respon Santri terhadap Bencana Alam di Lamongan Jawa Timur oleh Muhamad Rokib (2011), dan Interpretasi Pesantren atas Banjir oleh Hatim Gazali (2011).

Bencana merupakan fenomena sosial akibat kolektif atas komponen ancaman berupa fenomena alam/buatan di satu pihak, dengan kerentanan komunitas di pihak lain. Bencana terjadi apabila tingkat kemampuan sebuah komunitas untuk bertahan lebih rendah di banding tingkat ancaman yang mungkin terjadi. Bencana akan menurunkan kemampuan masyarakat dalam menguasai maupun mengaskses aset penghidupan bagi individu, lingkungan sosial, lingkungan alam, fisik infra-struktur maupun finansial, baik secara personal maupun masyarakat secara umum (Nuryani, 2011).

Pendekatan studi bencana dalam ilmu sosial menempatkan bencana sebagai bentuk perubahan sosial karena bencana dilihat dalam hubungannya dengan sejarah panjang dan evolusi umat manusia (Abdullah, 2006). Dengan menempatkan manusia dan masyarakat sebagai tumpuan analisis, maka letak persoalan bencana bukan hanya pada alam, melainkan bersumber pada ketimpangan kerentanan yang ada dalam masyarakat itu sendiri. Peringatan, proteksi, pengetahuan, keahlian, dan akses baik terhadap sumbersumber pengetahuan, jaringan, dan sumbersumber bantuan dapat memitigasi dampak kejadian alam dan meningkatkan kemampuan manusia untuk memulihkan efek yang ditimbulkan. Dengan demikian, sebenarnya tangan manusia ikut menentukan apakah sebuah kejadian dapat menjadi bencana atau sekedar kejadian alam biasa.

Pada makalah Seminar Internasional 
tanggal 20-22 Oktober 2009 yang berjudul The Structure and Culture of Disaster: Theory, Research and Policy, Irwan Abdullah menjelaskan tiga pendekatan untuk memahami bencana dari perspektif akademik. Pertama, pendekatan Teknokratik, yaitu pendekatan yang memahami bencana sebagai fenomena alam yang terpisah dengan pengalaman manusia, bencana dilihat sebagai pengalaman yang luar biasa atau di luar batas kewajaran manusia untuk menghadapinya. Kedua, pendekatan Behavioristik, yakni, sedikit merespons pendekatan teknokratik, pendekatan ini menggaris-bawahi peran individu, respons institusi, dan respons budaya yang mempertanyakan peran kelembagaan dari institusi sosial, agama, politik, kekuasaan, dan respons ekonomi secara global. Konstelasi dalam bencana pun terlihat yakni terjadinya perebutan ruang dari respons politik, kekuasaan yang memperdebatkan bagaimana sebaiknya menstabilkan kondisi pasca bencana, atau respons ekonomi yang selalu menempatkan bencana sebagai kondisi yang memporak-porandakan lingkungan fisik, materi, dan sekaligus menjadi sumber pengumpulan materi "economic boom" yang membuka peluang untuk mengumpulkan donasi, peluang kerja, dan pemasukan bagi beberapa kelompok tertentu (Dudasik, 1982; Button, 1995; Palinkas, 1993; Oliver-Smith, 1996; Irwan Abdullah, 2007).

Bencana juga memperbincangkan sisisisi perilaku manusia yang berhubungan dengan sifat-sifat kedermawanan, altruisme, pilihan rasional, dan kepemilikan harta pribadi. Adapun pendekatan yang ketiga adalah dimensi struktural bencana. Pendekatan struktural memberikan penekanan pada proses distribusi dana, pengaturan sumber daya materi, kekayaan, dan kekuasaan dalam komunitas yang dijadikan sebagai prakondisi dari bencana. Pendekatan struktural dengan proses yang baik akan membuka kemungkinan sebuah komunitas untuk menghindari atau melakukan upaya pemulihan bencana dengan lebih baik (Blaikie, 2003).
Komunitas atau kelompok warga juga dapat menjadi model pengalaman hidup bersama sebelum dan setelah terjadi bencana. Selain itu, bencana memberikan banyak kemungkinan, mengubah perilaku, kebiasaan, pola piker, dan pemahaman bahwa bencana bukan hanya persoalan fenomena alam, melainkan akibat ketidakseimbangan hubungan antar-struktur sosial dalam sebuah kelompok. Gagasan ini berasal dari pemikiran Marxisme struktural dan ekonomi politik yang berkembang pada era tahun 1980-an. Oleh karena itu, dibutuhkan proteksi, pengetahuan, akses baik terhadap pengetahuan maupun materi dan kemampuan manusia untuk mengembangkan dampak dari bencana (Balikie, 2003). Pendapat ini melihat lebih dekat hubungan antara kerentanan terhadap bencana yang berasal dari faktor sosial dari pada faktor alam itu sendiri.

Bencana memberikan perubahan pada kelompok yang tertimpa, perubahan itu bisa perubahan fisik maupun non-fisik, sebagian menuntut perubahan ekstrim yang bersifat cepat dan baik di satu sisi. Namun di sisi lain, juga terdapat dampak negatif, khususnya ketika rekonstruksi pasca bencana melibatkan banyak agen, yang sekaligus membawa sesuatu yang asing dan baru bagi masyarakat yang tertimpa bencana yang seringkali menimbulkan masalah baru bagi korban dan merusak struktur ataupun perilaku sosial. Sebagaimana Oliver-Smith (1996) dalam tulisannya menyebutkan bahwa donasi yang diberikan kepada korban bencana pada proses rekonstruksi justru dapat menjadi kondisi yang lebih membahayakan dari pada bencana itu sendiri.

Penelitian ini dilakukan dengan metode observasi lapangan, yaitu penggabungan beberapa pendekatan untuk memenuhi data yang dibutuhkan. Secara garis besarnya, penelitian ini menggunakan pendekatan metode kualitatif. Data di lapangan diambil dengan cara wawancara mendalam, setelah sebelumnya melakukan observasi dan pengamatan di wilayah sekitar Kali 
Putih. Data juga diperoleh dengan cara mengumpulkan referensi dari beberapa sumber pustaka yang meliputi metodologi dan teori-teori tentang penelitian bencana dan beberapa kajian khusus tentang perempuan dan bencana.

Pengambilan data lapangan dilaksanakan selama kurang lebih tiga bulan. Data lapangan diambil delapan bulan pasca terjadinya banjir lahar dingin di wilayah Dusun Gempol Desa Jumoyo, khususnya di Hunian Sementara (Huntara) Dusun Gempol Jumoyo. Data diambil sejak awal bulan Juli 2011 hingga September 2011. Kegiatan ini secara garis besar dilakukan pada musim kemarau, karena hujan tidak turun dan wilayah ini relatif aman dari banjir lahar dingin. Penulisan hasil penelitian dilakukan pada musim hujan, di mana beberapa ahli Geologi memperkirakan akan terjadi peluang banjir lahar dingin saat curah hujan meningkat. Hal ini disebabkan masih banyak material yang belum dikeluarkan oleh Gunung Merapi saat terjadi erupsi pada akhir tahun 2010 hingga awal tahun 2011. Terlepas dari perkiraan tersebut, penelitian ini terbatas hanya pada data yang disebutkan yaitu mulai bulan Juli hingga bulan November 2011. Oleh karena itu, hasil penelitian ini juga terbatas sesuai dengan tanggal terhitung data mulai diambil dan berakhir.

Data diperoleh dengan cara mendatangi informan ke rumah yang bersangkutan. Beberapa informan yang ditemui dan memberikan informasi di sela-sela pekerjaan rumah atau di tempat bekerja. Penelitian ini dilaksanakan pada fase pemulihan bencana sehingga persoalan-persoalan yang muncul lebih banyak pada persoalan untuk bertahan yang meliputi masalah tempat tinggal, jatah hidup, pekerjaan, dan lain-lain bukan lagi persoalan penyelamatan jiwa secara langsung dari tempat bencana.

Penelitian yang mengambil tempat di Huntara tentu memiliki kemudahan dan kesulitan dalam mengumpulkan data. Kemudahan memperoleh data karena sebagian besar responden berada di tempat yang sama dan lokasi tempat bekerja pun cenderung lebih dekat dan dilakukan secara komunal. Kesulitan perolehan data dikarenakan bencana mempengaruhi sebagian besar kondisi psikologis masyarakat yang kehilangan harta benda dan juga berdampak pada hubungan inter dan antarpersonal, di antaranya kecurigaan atas ketidak-merataan pembagian bantuan atau jatah hidup. Hal ini menyulitkan peneliti untuk melakukan kegiatan yang melibatkan beberapa orang. Seperti yang terjadi ketika kepala dusun hanya mengumpulkan beberapa anggota warga Huntara, warga yang tidak dipanggil langsung bereaksi dengan kecurigaan dan alasan kekhawatiran jika perkumpulan tersebut dalam rangka pembagian bantuan.

Persoalan lain adalah tumbuhnya kerentanan psikologis khususnya di kalangan perempuan sehingga proses wawancara dan penggalian data terkadang dijadikan tempat untuk mengadu, mengiba, dan berkeluh kesah. Meskipun hal ini sangat wajar, namun kecenderungan yang terlihat dari korban adalah meminta bantuan jauh lebih besar dari pada kemauan untuk bangkit dan berjuang. Selain itu, keterbatasan waktu dalam penelitian ini tentu sangat berpengaruh pada hasil yang diperoleh. Oleh karena itu, masih terbuka kemungkinan untuk terus memperbaharui dan memperkaya data dan kajian seputar perempuan dan bencana.

\section{PEMBAHASAN \\ Gambaran Umum}

Hunian Sementara (Huntara) Dusun Gempol Desa Jumoyo Kecamatan Salam Kabupaten Magelang, Jawa Tengah didirikan di lapangan sekolah yang biasanya digunakan untuk upacara setiap tanggal 17 Agustus dan kegiatan besar lainnya. Saat ini, sudah tidak ada lahan lain di lapangan kecuali beberapa petak lahan parkir mobil di bagian depan kompleks Rumah Hunian Sementara. Adapun kondisinya, tiap atap terdiri dari dua gandeng rumah atau bentuk couple $12 \mathrm{~m} \times 6 \mathrm{~m}, 1 \mathrm{kk}$ menempati $6 \mathrm{~m} \times 6 \mathrm{~m}$, terdiri ruang tengah, 2 kamar tidur, 1 kamar 
mandi, 1 dapur kecil di bagian belakang, kamar mandi, dan kakus juga tersedia di setiap rumah, namun septictank disediakan satu bagi setiap dua keluarga atau bagi setiap dua rumah.

Semua rumah yang dibangun di area ini dibuat dengan bahan dasar gedhek dan asbes sebagai atapnya. Tidak ada plafon atau eternit yang menutupi langit-langit setelah atap. Akibatnya, bukan hanya udara dingin yang bisa langsung dirasakan, tetapi juga tidak ada penyadap suara sehingga suara apapun bisa terdengar kepada sesama tetangga. Beberapa penghuni rumah mulai mengisi rumah mereka dengan layar televisi baru berukuran 29 inch yang semakin menambah banyak suara di setiap rumah. Menurut para relawan, kondisi ini dapat dimaklumi sebagai sarana bagi para penghuni Huntara untuk menyamankan diri karena tinggal di tempat baru yang berbeda dari sebelumnya meskipun beberapa pihak lain menyatakan bahwa televisi semakin membuat ketidaknyamanan untuk hidup berdampingan karena dapat mengganggu ketenangan tetangga terdekat.

Satu couple Huntara yang berada di bagian paling depan kompleks digunakan sebagai tempat bersama untuk beberapa komunitas voluntir, seperti Gerakan Pemuda (GP) Anshor Nahdatul Ulama (NU), Komunitas Radio Merapi, dan juga untuk base camp Mahasiswa KKN UGM. Adapun Pak Dukuh, sebagai kepala dan penanggung jawab area Huntara menempati rumah paling depan berdampingan dengan rumah ibunya. Sepanjang jalan di daerah hunian sementara sudah di-cor permanen, mengelilingi kompleks. Di luar komplek, sebuah rumah dijadikan tempat mangkal para ibu-ibu penghuni Huntara sebagai tempat pembuatan keset, program pembuatan keset ini adalah program pasca terjadinya banjir lahar dingin, tepatnya setelah warga menetap di Huntara. Program ini dilakukan atas bantuan "Balai Besar Rehabilitasi Sosial Tuna Grahita Kartini Temanggung" dengan modal awal pemberian bahan sebanyak 500 $\mathrm{kg}$ dan 5 buah alat pemintal keset.

\section{Peran Perempuan dalam Bencana}

Hubungan sosial menjadi semakin rumit saat terjadi krisis sosial akibat bencana. Oleh karena itu, bencana alam menjadi realistic laboratory untuk mempelajari fenomena sosial masyarakat, sekaligus menjadi media untuk melihat hubungan masyarakat (Fothergill, 1999). Karena bencana memberikan banyak penjelasan dan pengetahuan yang terkadang mengubah beberapa kebiasaan yang terjadi dalam waktu normal. Hal tersebut bisa berupa adat istiadat, kebiasaan, pekerjaan, bahkan orientasi hidup. Saat terjadi bencana perempuan memiliki cara bertahan namun sekaligus menjadi kelompok yang lebih rentan dibanding kaum laki-laki. Bencana seringkali membuat perempuan terlihat lemah dan tergantung baik pada kaum laki-laki, pemerintah ataupun para pemberi bantuan. Pasca bencana lebih sedikit perempuan yang mendapatkan akses pada program pemulihan, seperti pada akses pendidikan atau keterampilan, karena tidak banyak yang dapat terlibat dalam bidang sosial politik maka seringkali kebijakan yang dikeluarkan tidak berpihak pada kaum perempuan (Enarson, 1998a).

Kerentanan gender dalam bencana tidak hanya disebabkan oleh faktor relasi dalam rumah tangga atau kemiskinan, tetapi faktor sejarah dan budaya juga ikut berpengaruh, termasukgayahidupdankepribadian. Faktorfaktor tersebut saling bersentuhan dengan faktor ekonomi, ras, dan ketidaksetaraan lainnya. Hubungan-hubungan tersebut menciptakan kondisi bencana sosial yang memunculkan risiko bencana yang lebih hebat dari sekedar bencana alam yang telah ada (Blaiki et al, 2002). Globalisasi ekonomi pun memberi kontribusi bagi komunitas dan populasi gender yang secara spesifik mempengaruhi kaum perempuan sebagai konsumen, pemerhati, pengguna layanan sosial, dan pelaku ekonomi (Enarson, 1998b).

Agar dapat memahami kerentanan perempuan sebagai korban bencana, dibutuhkan pemahaman yang menyeluruh. Hal ini dapat dilakukan melalui pemahaman 
ekonomi secara global. Beberapa hal yang dapat dilakukan untuk memahami potensi perempuan korban melalui tiga bentuk pendekatan yaitu komunitas, tempat kerja, dan keluarga atau wilayah domestik. Berikut ini diuraikan kondisi-kondisi yang berhubungan dengan komunitas perempuan pada wilayah bencana pasca letusan Merapi.

\section{Komunitas atau Kelompok}

Sebelum terjadi bencana, perempuan warga Dusun Gempol memiliki beberapa kegiatan sosial kemasyarakatan maupun keagamaan. Di dalam bidang agama, salah satu organisasi yang aktif di dusun ini adalah Fatayat NU. Selain aktivitas rutin pengajian keagamaan, masyarakat yang beragama Islam memiliki beberapa kegiatan lain seperti kenduri/slametan untuk kelahiran, pernikahan, dan kematian. Banjir lahar dingin yang memaksa warga meninggalkan rumah dan menetap di tempat yang baru, kini mengalami banyak perubahan di dalam kehidupan sehari-hari. Pasca banjir lahar dingin, sebagian besar warga tinggal di Huntara, bercampur dengan beberapa warga lain dari warga kelompok yang berbeda secara geografis (tidak sesuai dengan kelompok RT/RW), dengan bahasa lain Kepala Dusun menyebutnya sebagai tatanan yang amburadul. Dampak dari perubahan ini adalah kegiatan atau aktivitas yang biasanya rutin dilakukan saat ini mandeg, dengan alasan penyebaran anggota dan tidak tersedia ruang untuk berkumpul.

Dalam bidang sosial ekonomi, warga menyelenggarakan arisan bulanan. Kegiatan menabung sekaligus menjadi wadah untuk berbagi informasi, cerita atau sekedar berkumpul bersama. Saat ini kegiatan arisan tetap berjalan, namun hanya sekedar pengumpulan uang oleh koordinator, tidak ada lagi pertemuan bersama, dengan alasan yang sama, tidak ada ruang atau tempat yang layak untuk berkumpul. Selain itu, Program Pemberdayaan Kesejahteraan Keluarga (PKK), termasuk di dalamnya Pos Pelayanan Terpadu (Posyandu), yaitu kegiatan bulanan yang diselenggarakan untuk meningkatkan gizi ibu hamil, ibu menyusui, dan balita, saat ini sudah tidak lagi berjalan, dengan alasan koordinator kegiatan yang tidak menetap di Huntara.

Bencana, dalam hal ini banjir lahar dingin, dapat memperluas kesempatan masyarakat mengenal kelompok atau orang lain, baik tetangga baru yang menetap di Huntara, maupun kelompok relawan dan donatur yang datang dengan bantuan maupun kegiatan pendampingan, namun sekaligus mengurangi dan membatasi apa yang sebelumnya telah dimiliki sebagai kesatuan dalam kelompok (Forthgill, 1999). Bencana membuka peluang terjadinya diskontinuitas yang diakibatkan oleh faktor diluar kelompok itu sendiri dan dengan munculnya kelompok atau kesempatan baru. Faktor kedua yang berdekatan dengan isu perempuan adalah pekerjaan yang muncul setelah terjadinya bencana.

\section{Pekerjaan}

Banjir lahar dingin selain mengubah perilaku warga Gempol, juga mengubah mata sistem mata pencaharian. Sebelum banjir lahar dingin sebagian besar warga bekerja pada sektor pertanian; bertani dan berladang baik bagi yang memiliki lahan maupun yang bekerja sebagai buruh tani. Karena sebagian besar lahan tertutup pasir abu Gunung Merapi maka muncul alternatif pekerjaan setelah banjir lahar dingin. Kebutuhan pemenuhan biaya hidup sehari-hari dan berlimpahnya materi untuk diolah, menjadi sebuah ketepatan untuk meningkatkan penghasilan masyarakat di sekitar aliran Kali Putih. Adapun profesi baru yang menjadi pilihan warga setelah terjadi banjir lahar dingin sangat beragam.

Penambang Pasir. Tarmiyati adalah salah satu perempuan penambang pasir pasca banjir lahar dingin, alasannya ikut menambang karena suaminya juga sudah menambang pasir sejak sebelum terjadi banjir lahar dingin. Kelimpahan material lahar dingin dengan upah yang cukup besar membuatnya tertarik untuk bergabung, namun baginya menambang pasir hanya 
menjadi pekerjaan sambilan, karena badan tidak cukup mampu bekerja lebih keras. Manfaat lain yang ia peroleh setelah ikut menambang pasir adalah munculnya empati yang lebih tinggi atas usaha dan kerja suami:

"sekarang saya sudah tau rasanya kerja itu berat, apalagi jadi penambang pasir, jadi bisa paham kalau suami pulang itu capek, dulu itu kalau di kasih uang belanja tapi gak cukup, saya kadang pingin marah, karena uangnya gak cukup buat kebutuhan seharihari, tapi saya gak berani bilang, kalau sekarang saya sudah maklum, berapapun uang yang dikasih saya terima, karena kerja nambang itu tidak mudah (wawancara tanggal 31 Juli 2011)".

Tercukupinya kebutuhan sehari-hari adalah hal paling penting baginya agar memenuhi kebutuhan biaya sekolah dan jajan anaknya yang masih duduk di bangku sekolah dasar.

Selain Tarmiyati, juga ada Surti, perempuan berusia 33 tahun, dengan tiga orang anak. Anak paling besar Surti sudah duduk di bangku SMP kelas tiga. Surti terlihat tangguh di usianya yang masih muda, sebagian wajah dan badannya berwarna agak gelap, karena setiap hari bersama dengan suaminya, ia pergi menambang pasir bawaan banjir lahar dingin. Menurut pengakuannya menambang pasir bukan tanpa alasan, "ketiga anak saya harus sekolah", dengan motivasi agar bisa menghidupi keluarga dan memberikan pendidikan yang lebih baik bagi anak-anaknya. Namun dia tidak bisa terlibat aktif pada kegiatan-kegiatan di Huntara, seperti membuat keset bersama para perempuan lain, tetapi ia tetap berusaha untuk hadir di setiap kegiatan sosial maupun hajatan warga di area Huntara.

Lain halnya dengan Suharni, perempuan paruh baya berusia lebih dari 50 tahun, yang tinggal di Huntara bersama dengan suaminya. Mereka menjalani profesi sebagai penambang pasir paruh waktu dengan prinsip secukupnya dan semampunya. Artinya, tidak terlalu ngoyo namun juga tidak bisa terlalu lambat. Suaminya mengalami patah tulang sejak beberapa tahun yang lalu sehingga pekerjaan menambang pasir dilakukan secukupnya saja, agar tidak membahayakan keselamatan dan kesehatannya. Salah satu alasan bagi banyak perempuan yang tertarik ikut menambang pasir adalah karena upah yang besar berkisar Rp 55.000 - Rp 60.000/hari (jika pasir laku terjual).

Selain tiga perempuan di atas, perempuan lain yang berprofesi sebagai penambang adalah Karsumi. Ia menjadi penambang pasir sebelum terjadi erupsi (2004-2006). Saat ini, ia tidak lagi menjadi penambang, melainkan mencari pasir di lereng Gunung Merapi, bersama suaminya. Mereka membangun gubuk kecil di tempat panambangan, sebuah bilik berukuran $2 \mathrm{~m}^{2}$ didirikan dengan tujuan menghemat pengeluaran untuk transportasi. Mereka pulang ke rumahnya di Dusun Gempol sekitar 2 minggu sekali. Karena tidak mempunyai anak, mereka bisa pulang kapan saja. Karsumi merasa bahwa pekerjaan menambang pasir di gunung bisa dilakukan dengan sesuka hati, tidak ada aturan yang mewajibkan harus datang setiap hari. Bersama dengan suaminya, ia memperoleh pendapatan Rp 80.000/ hari, setiap kali mereka berhasil menjual 1 rit (8 kibik).

Pekerjaan buruh pasir perempuan biasanya mencari pasir di sungai. Alasannya, pasir relatif lebih ringan dengan alat slenggrong tidak seperti pasir di daratan (karena mengendap sehingga keras dan berat untuk di cangkul). Pasir yang ada di sungai digali/ditambang, dientas atau ditiriskan agar kadar airnya berkurang, timbunan pasir nantinya akan menjadi bukit-bukit kecil yang dijual penambang pasir kepada pemilik truk. Satu rit (8 meter kubik, dihargai 60 ribu). Baik buruh muat (yang memuat pasir dari bawah ke dalam truk) maupun buruh bongkar pasir (yang menuang pasir dari dalam truk diturunkan ke bawah) harus memiliki bahu yang kuat untuk menopang beban pasir. Karena pembayaran berdasarkan seberapa banyak jumlah pasir yang dikumpulkan ke dalam truk, maka baik laki-laki maupun perempuan tidak mengalami perbedaan dalam upah. Hal ini yang berbeda dengan 
pilihan pekerjaan sebagai buruh tani yang membedakan upah laki-laki dan perempuan dan memberikan upah bagi perempuan di bawah upah untuk laki-laki.

Pasca erupsi dan banjir lahar dingin nilai upah pekerja menjadi lebih tinggi disebabkan program rehabilitasi pasca bencana. Melalui program padat karya yang diselenggarakan oleh Pemerintah bekerjasama dengan PNPM Mandiri, warga memperoleh peluang kerja dengan cara membersihkan jalan dan faslitas umum lainnya dengan upah minumum di atas rata-rata pekerjaan buruh bangunan. Pada akhirnya ketika program berakhir, upah buruh bangunan di sekitar wilayah Kali Pasir juga ikut naik sesuai standar upah program padat karya. Hal ini tentu saja merugikan pihak pengguna jasa buruh bangunan yang terkena dampak tidak langsung dari program pasca banjir lahar dingin.

Pilihan pekerjaan para perempuan untuk menjadi penambang pasir khususnya beberapa saat setelah terjadi banjir lahar dingin menunjukan penghilangan batas pekerjaan berdasarkan gender, di mana Julie Cuppless (2007) menyebutkan dalam kasus korban Badai Mitch di Nikaragua, yaitu laki-laki dan perempuan bekerjasama membangun kembali rumah yang rusak oleh badai sebagai "no more traditional gender relation" atau sudah tidak ada lagi hubungan tradisional gender saat bencana terjadi, karena baik laki-laki maupun perempuan dapat terlibat dan mempunyai peran yang sama penting.

Penjual Makanan. Profesi dadakan lain setelah tejadinya banjir lahar dingin adalah berdirinya warung-warung tenda makanan untuk memenuhi permintaan atau memberikan penawaran bagi pengunjung yang datang ke lokasi banjir lahar dingin, juga bagi para pekerja/penambang pasir. Sebagian pedagang membuka warung setelah banjir lahar dingin, sebagian yang lain sudah membuka warung sejak sebelumnya. Makanan yang ditawarkan antara lain jajanan anak-anak, es, soto ayam, bubur ayam, dan gorengan. Makanan tersebut dapat dibuat dengan cara mudah dan dengan modal kecil sehingga para pedagang dapat sekaligus menikmatinya. Para pedagang warung makanan ini merupakan representasi faktor ekonomi yang mengambil peluang saat terjadi bencana. Hal ini menguntungkan bagi para penjual, dan para konsumen, namun sekaligus menimbulkan peluang lebih luas atas kebutuhan konsumsi tambahan bagi para korban yang berada disekitar huntara dan kali putih.

Pengrajin Keset. Pasca banjir lahar dingin beberapa pelatihan diberikan bagi pengungsi. Pelatihan dikelola oleh pihak pemerintah desa dan Gerakan Pemuda (GP) Anshor. Pelatihan membuat aksesoris dan pelatihan tata boga yang diberikan oleh Pemerintah Provinsi Jawa Tengah, namun keduanya hanya terealisasi pada proses pelatihan tanpa tindak lanjut. Khusus pada pelatihan boga meskipun pemerintah telah memberikan alat membuat roti yang lengkap, namun masyarakat tetap belum mengembangkan usaha ini. Sementara itu, pembuatan aksesoris selain terkendala modal, warga juga tidak cukup tekun menjalankannya. Penanggung jawab kegiatan ini adalah ibu kepala desa. Kondisi ini juga menimbulkan kendala lainnya, yaitu warga merasa sungkan untuk menanyakan kepada ibu kepala desa tentang bantuan modal usaha dan metode pemasaran yang dikelola oleh GP Anshor. Selain dua pelatihan tersebut, terdapat juga Pelatihan Membuat Kerajinan Keset dari Balai Besar Rehabilitasi Sosial Tuna Grahita Kartini, Temanggung, dengan modal awal pemberian bantuan lima buah alat dan bahan (kain) 500 kg. Kaum perempuan lebih banyak tertarik untuk menjalankan ketrampilan ini karena tingkat kesulitannya rendah, selain itu pemasarannya juga mudah, selain dipasarkan ke beberapa sekolah, juga dapat dijadikan souvenir bagi setiap tamu atau donatur yang datang.

\section{Keluarga}

Domain privat perempuan selalu identik dengan ruang lingkup domestik di mana perempuan ditempatkan secara tradisional untuk berada di rumah. Akan tetapi, banjir 
lahar dingin telah melibatkan pengalaman perempuan untuk merepresentasikan sesuatu yang lebih kompleks, meskipun pada kenyataannya masyarakat masih tidak cukup memberikan perhatian khusus bagi mereka. Seolah tidak ada yang bermasalah ketika muncul ketidakstabilan hubungan sosial-ekonomi pasca bencana. Baik laki-laki maupun perempuan diberikan tanggapan atau respons yang sama. Padahal, untuk membangun mental masyarakat secara menyeluruh, salah satu jalannya adalah melalui kaum perempuan karena mereka merupakan jalan untuk menjaga stabilitas masyarakat melalui keluarga. Lain halnya kondisi yang terjadi di lapangan. Di mulai dari lokasi Huntara yang terlalu sempit, keterbatasan ruang privat yang secara psikologis membuat ketidak-nyamanan untuk mengekspresikan banyak hal, yang juga di dalamnya ada banyak yang harus dijaga oleh kaum perempuan ketika mereka menetap di Huntara. Dengan kondisi rumah yang berdekatan, tidak kedap suara dan tanpa pekarangan, perempuan dituntut untuk memenuhi kebutuhan sehari-hari di rumah, memasak, melakukan aktivitas yang tidak mengganggu kenyamanan tetangga, dan tetap melayani suami baik batin maupun lahir (biologis).

Perempuan sebagian besar menerima kodratnya untuk berada di wilayah domestik, tetapi bukan berarti dibiarkan tanpa fasilitas yang sesuai dengan kebutuhannya. Ada banyak hal yang perlu untuk diperhatikan jika masyarakat menginginkan pemulihan bencana secara menyeluruh, yaitu terpenuhi lahir dan batin korban bencana. Dampak terbesar dari bencana sesungguhnya bukan hilangnya harta benda, melainkan gesekan antar-warga, kecurigaan, dan hilangnya sensitivitas sosial antara korban sehingga menimbulkan bencana sosial yang lebih besar. Setiap kali mereka ditanya apa yang akan dilakukan setelah bantuan tidak lagi ada, sebagian besar menjawab, "urusan nanti ya tidak usah dipikirkan sekarang".

Persoalan lain yang muncul adalah sebagian besar para ibu mengeluhkan masalah baru sejak menetap di Huntara. Warung dadakan kini mulai marak beroperasi di setiap blok Huntara yang menawarkan berbagai makanan. Akibatnya, semakin meningginya tingkat konsumsi anak-anak termasuk juga orang dewasa. Keluhan lain oleh para ibu terhadap kebiasaan anak-anak sejak di Huntara adalah semangat dan prestasi belajar yang menurun. Huntara dengan kondisi sangat minimalis tidak cukup kondusif untuk belajar, karena ruang yang sempit dan tanpa jarak, tidak ada ruang privasi maupun pekarangan sehingga setiap obrolan, suara radio, dan televisi milik tetangga lebih banyak terdengar masuk ke dalam rumah, kondisi ini justru membuat anak-anak semakin tertarik untuk menyalakan pesawat televisi, menikmati hiburan, dan meninggalkan tugas belajar.

Persoalan-persoalan yang muncul di Huntara adalah bentuk respons warga yang mencoba membangun kembali kehidupan setelah mengalami bencana yang mengubah hidup mereka. Rumah sebagai tempat tinggal menjadi begitu penting karena memiliki makna yang tidak sekedar sebagai tempat perlindungan, melainkan juga sebagai identitas dan kepribadian. Oleh karena itu, saat rumah hilang terbawa banjir lahar dingin, maka timbul persoalan yang dalam hal ini Oliver Smith (1996) mengambil hubungan antara keterikatan batin dengan tempat, diri, dan definisi sosial.

Dari ketiga peran tersebut di atas, untuk aktif terlibat dalam kegiatan masyarakat baik yang berhubungan dengan bencana maupun tidak yang dapat dilakukan melalui keaktifan atau keterlibatan dengan pihak lain, menjadi dua pilihan yang dapat mempercepat masa pemulihan bencana. Kedua hal tersebut memaksa perempuan untuk terlibat dan berinteraksi sehingga dapat memperkaya pengalaman hidup bersama. Meskipun pilihan menetap di rumah, namun mengurus segala keperluan rumah tangga juga tetap harus diperhatikan

Pada akhirnya, penanggulangan bencana membutuhkan teori dan praktik yang disertai analisis gender sebagai 
dasarnya, karena ketidaksetaraan gender semakin memperbesar tingkat kerentanan bencana khususnya bagi kaum perempuan terlebih yang tinggal di negara berkembang (Sen, 2005). Hal ini dikarenakan pemerintah, khususnya pada pengolahan dan pengembangan kebijakan publik, belum mampu memenuhi kebutuhan warganya terlebih bagi kaum perempuan. Jika perempuan tidak dilibatkan dalam programprogram pemberdayaan, maka dapat dipastikan berpeluang menjadi bentuk lain dariketergantungan(Cupplies,2007) selainitu akan semakin mempersulit proses pemulihan setelah terjadinya bencana. Kondisi ini sudah terlihat pada ketidak-pahaman masyarakat yang bertujuan membantu dan meringankan beban para korban. Sebaliknya, memberikan efek bencana lanjutan yaitu bencana sosial dan psikologi, yang buruk bagi para korban, antara lain ketergantungan, kesulitan untuk bangkit dan meningkatnya konsumsi masyarakat korban karena kelimpahan donasi yang diperoleh dan sekaligus meningkatnya beberapa harga bahan pokok karena kelangkaan saat terjadi bencana, yang sekaigus menaikan gaji dan honor pekerja, sebagai bentuk dari economic boom (OliverSmith, 1996; Abdullah, 2007). Hal ini dapat disebut sebagai simptom hubungan sosial yang dilematis bagi masyarakat korban bencana.

\section{SIMPULAN}

Perempuan yang tinggal di Huntara pasca banjir dihadapkan pada kondisi yang dilematis. Jarak yang terlalu dekat dengan tetangga membuat kondisi perempuan tidak nyaman secara psikologis. Mereka bisa menjadi tontonan atau menonton tetangga kiri dan kanan, terlebih banyaknya bantuan dari pemerintah maupun pihak swasta membuat perempuan-perempuan ini merasa nyaman menunggu dan menerima bantuan daripada mengeluarkan peluh untuk menambah pemasukan. Dampak dari perilaku tidak produktif ini salah satunya dapat dilihat dari kebiasaan para perempuan penghuni Huntara hanya selalu menghabiskan waktu dengan duduk-duduk dan ngobrol dengan tetangga. Kesenangan dan kemudahan dalam waktu yang singkat ini sudah cukup membuat masyarakat tidak bisa berpikir untuk jangka panjang. Padahal, ada puluhan keluarga yang tinggal diHuntara dan anak-anak yang harus menatap masa depan lebih panjang. Jika orang tuanya tidak punya visi dan jelas dan ia tidak didukung oleh lingkungan yang kondusif, maka dapat dimungkinkan sepuluh sampai dua puluh tahun ke depan negara akan menangggung beban berat oleh karena semakin banyak warga negara yang tidak produktif.

Perlu pendekatan yang holistik untuk membenahi masyarakat korban bencana, pendekatan yang tidak menyeluruh hanya akan menyelesaikan sebagian saja dari masalah. Penanganan bencana harus dimulai dari apa yang dipikirkan dan dirasakan oleh korban, maka hal ini dapat dimulai dengan memberikan akses kepada korban bencana yaitu melalui pemahaman yang salah satunya dapat dilakukan melalui pendidikan baik formal maupun non-formal. Pendidikan memang membutuhkan proses yang lama, namun ia punya kekuatan yang cukup besar untuk melakukan perubahan. Jika pemerintah maupun pihak donatur atau masyarakat ingin melakukan perubahan yang lebih baik bagi warga korban bencana maka mulailah dengan mendidik kaum perempuan, karena merekalah yang menjadi mediator dalam keluarga sekaligus sekolah pertama bagi anak-anaknya, karena dampak bencana selain kerusakan fisik yang harus dibantu, dibangun, dan diobati adalah mental dan jiwa para korban. Oleh karena itu, penelitian ini berupaya untuk memberikan rekomendasi agar para pihak pengambil kebijakan selain memberikan bantuan materi juga dapat mengembangan mental melalui pendidikan agar para perempuan lebih maju dan cepat bergerak untuk merespons dan me-recovery keadaan pasca bencana. Hal ini perlu dilakukan untuk sekaligus meningkatkan kemandirian dalam keluarga dan kemandirian sosial. Kemandirian sosial pada akhirnya juga akan berpengaruh pada 
kemadirian ekonomi.

Adapun beberapa elemen yang berpeluang menjadi jalan masuk untuk mulai mengembangkan kemandirian sosial dan ekonomi. Pertama, komunitas dan kelompok perempuan, baik yang bergerak dalam bidang ekonomi (koperasi, arisan), sosial (Posyandu), maupun religi (kelompok pengajian), dari komunitas yang telah terbentuk dapat digalakkan kembali. Kedua, pekerjaan. Hal ini dapat dilakukan melalui pendampingan usaha bersama maupun pribadi yang saat ini banyak ditemui seperti para pedagang dadakan baik di Huntara maupun di daerah lokasi bencana, maupun kelompok unit usaha yang terbentuk setelah terjadi bencana (pengrajin keset dan penambang pasir). Ketiga, keluarga. Ia berfungsi sebagai basis kekuatan sosial masyarakat yang kuat dan tangguh dalam merespons dan bangkit setelah terjadi bencana. Dengan demikian, perlu kerjasama dari berbagai pihak, meliputi lembaga pemerintah maupun lembaga swasta dan perlu dilakukan kajian lebih lanjut mengingat penelitian tentang masyarakat tidak cukup dilakukan hanya satu kali, karena masyarakat adalah subjek yang cair dan selalu mengalami perubahan.

\section{DAFTAR PUSTAKA}

Abdullah, Irwan, 2006, "Dialektika Natur, Kultur, dan Struktur: Analisis Konteks. Proses dan Ranah dalam Konstruksi Bencana", Pidato Guru Besar Universitas Gadjah Mada, 13 November 2006. Yogyakarta: Sekolah Pascasarjana UGM , 2009, “The Structure and Culture of Disaster: Theory, Research and Policy", International Seminar. Disaster: Theory, Research, and Policy, tanggal 20-22 Oktober 2009. Yogyakarta: The Graduate School, Gadjah Mada University.

A., Gordon Macdonald, 1972, Volcanoes, Englewood Cliffs: New Jersey, Prentice-Hall, Inc.
Blaikie, P, 2002, "Vulnerability and Disaster" in V Desai and R. Potter (ed.), The Companion to Development Studies. London: Arnold.

Cupples, Julie, 2007, “Gender and Hurricane Mitch: Reconstructing subjectivities after Disaster", Journal Compilation, Overseas Development Institute. New Zeland: University of Canterbury.

Data Dasar Gunungapi Indonesia, 1979, Direktorat Vulkanologi. Departemen Pertambangan dan Energi. Republik Indonesia.

Enarson, Eleine, 1998a, Through Woman's Eyes: A Gendered Research Agenda for Disaster Social Science. Elaine Enarson. Disaster Preparedness Resources Centre. University of British Columbia. 1998b, Gender Patterns in Flood Evacuation: A Case Study in Canada's Red River Valley. University of British Columbia. Joseph Scanlon. Carleton University.

Fothergill, Alice, 1999, Woman's Roles in Disaster. Applied Behavioral Science Review. Vol.7/No. 2. Colorado: University of Colorado.

Fordham, Maureen H, 1998, "Making Woman Visible in Disasters: Problematising the Private Domain", dalam Journal Disasters, 22(2): 126-143.

J. Homan, 2003, "Social Construction of Disaster" In Mark Pelling Ed. Natural Disaster and Development in a Globalizing World. London: Routledge.

Laksono, PM. 1985. "Persepsi Setempat dan Nasional Mengenai Bencana Alam: Sebuah Desa di Gunung Merapi", in M.R. Dove (ed.). Peranan Kebudayaan Tradisional Indonesia dalam Modernisasi. Jakarta: Yayasan Obor Indonesia. 
Najarian. Louis M, Armen K. Goenjian, David Pelcovitz, Francine Mandel, Berj Najarian, 2001, "The effect of Relocation After a Natural Disaster", dalam Journal of Traumatic Stress Vol. 14 No. 3.

Nizam, 2010, “Bencana Alam sebagai Momentum Revitalisasi Ketangguhan Bangsa", dalam Pidato Ilmiah Dies Natalis ke-61 Universitas Gadjah Mada. 19 Desember 2010.
Oliver Smith, 1996, "Anthropological Research on Hazards and Disasters", dalam Annual Review of Antropology, Vol. 25.

2002," Theorizing Disaster: Nature, Power, and Culture", in S.M. Hoffman and A. Oliver-Smith (ed.). Catastrophe and Culture: The Anthropology of Disaster. Santa Fe: School of American Research Press.

Sen, Amartya, 2005, Ethics, Development and Disaster, Text of keynote address at the Ethics and Development Day at the IDB (Inter-American Development Bank) on January 11. 